\title{
Federalism and Foreign Affairs in Canada and the European Union: The Search for Equal Autonomy
}

\author{
Thomas Verellen $^{*}$
}

\begin{abstract}
This paper examines how two federal-type polities, Canada and the European Union, have addressed the tension between international law's fundamental value of State sovereignty and the constitutional value of federalism as it is professed in domestic settings. The paper argues that in both polities, federalism is still, to a large extent, put 'on hold' in the area of foreign affairs. Despite an increase in international activities by Canadian provinces since the 1960s, and despite the emergence of the European Union as a foreign policy actor of significance, in constitutional terms the authority to act internationally is still to a significant extent held or controlled by the order of government recognised as a sovereign State. In contrast to Canada, however, the dominance of the sovereign State in the area of EU foreign affairs is liable to spill over into the EU's domestic constitution. This observation calls for a recalibration of the federal balance in Europe's foreign affairs constitution. Such a recalibration, it is suggested, should start by critically reappraising the use of the technique of mixity.
\end{abstract}

\section{Keywords}

Comparative federalism, Foreign relations law, External action, European Union, Canada

\section{Introduction}

A tension exists between international law's fundamental value of State sovereignty and the value of federalism as it is professed in domestic settings. ${ }^{1}$ Under domestic

* $\quad$ PhD Candidate at Institute for European Law, University of Leuven. Special thanks to Professor Geert De Baere and Stefan Sottiaux for their comments on an earlier draft and to Ms Laura Smith and Mr Evan Smith for proofreading the final paper. All errors remain my own.

1 On this topic, see also Ivan Bernier, International Legal Aspects of Federalism (Archon Books 1973) 1. 
constitutional law, government power is considered to be divided between orders of government. ${ }^{2}$ Under international law, by contrast, such divisions of power matter little. Thus, for example, in the context of international responsibility, the conduct of a State shall be considered an act of that State, 'whatever position it holds in the organization of the State, and whatever its character as an organ of the central Government or of a territorial unit of the State. ${ }^{3}$ Similarly, the Vienna Convention on the Law of Treaties provides that, exceptions notwithstanding, 'a party may not invoke the provisions of its internal law as justification for its failure to perform a treaty.

Traditionally, this tension between a constitutional regime of divided power and an international legal order by and for unitary, sovereign States was resolved through the construction of a dualist 'wall' or 'veil' between the domestic and the international realms, whereby federalism was considered to stop at the water's edge. The United States is perhaps the best known example of this phenomenon, albeit not the only one. ${ }^{5}$ In that country, the federal Congress enjoys an implied power to implement treaties into domestic law, even if in a strictly domestic context the power to legislate on the subject of the treaty would come to the States. ${ }^{6}$ Similarly, the President and, to a lesser extent, Congress hold broad powers to conduct foreign affairs. ${ }^{7}$ The exercise of these powers can, under certain conditions, preempt the exercise of powers by the States. ${ }^{8}$ The justification for the existence of such

Kenneth Wheare, Federal Government (OUP 1964) 10; and more recently, Daniel Halberstam, 'Comparative Federalism and the Role of the Judiciary' in Gregory A Caldeira, Daniel Kelemen and Keith E Whittington (eds), The Oxford Handbook of Law and Politics (OUP 2008) 142 , defining federalism as 'the coexistence within a compound polity of multiple levels of government each with constitutionally grounded claims to some degree of organizational autonomy and jurisdictional authority'.

3 ILC, 'Draft Articles on Responsibility of States for Internationally Wrongful Acts' (12 December 2001) UN Doc A/RES/56/83, art 4(1).

4 Vienna Convention on the Law of Treaties (adopted 23 May 1969, entered into force 27 January 1980) 1155 UNTS 331 (Vienna Convention) art 27.

5 In the German context, see art 32(3) of the Basic Law, requiring prior federal consent to the conclusion of an international agreement.

6 See Missouri v Holland, 252 US 416 (1920); For a critique on the position of the Supreme Court in Missouri, see Justice Scalia's concurrent opinion in Bond v United States, 572 U.S.

7 For the most sweeping expression of the exclusively federal character of the power over foreign affairs, see United States $v$ Curtiss-Wright Export Corp, 299 US 304 (1936).

8 See, seminally, Zschernig v Miller, 389 US 429 (1968), in which the US Supreme Court invalidated a State statute for intruding in the federal realm of foreign affairs in which the President upheld an executive policy; For a recent example of the pre-emptive effect of the exercise of the President's foreign affairs powers on State law, see American Insurance Association v Garamendi, 539 US 396 (2003). 
broad powers is often functional in nature: the specific context of foreign affairs requires the federal government to hold broader powers than it does in a strictly domestic context. ${ }^{9}$

As long as international law's purpose was to allow the different members of the international community each to pursue their own conception of the good life, ${ }^{10}$ the restriction of federalism to the domestic realm was not considered overly problematic. When the predominant purpose of international law changed, however, from that of pursuing the peaceful co-existence of distinct political communities to that of pursuing what were considered shared goals and values, such as the defence of human rights, or the integration of the global economy, ${ }^{11}$ the exclusion of foreign affairs from the application of domestic constitutional principles, including the principle of federalism, was put into question. To name but one example of such critiques, in a 1991 book, American international lawyer Thomas Franck wondered: 'What is the point of a carefully calibrated system of divided and limited power if those who exercise authority can secure an automatic exemption from its strictures merely by playing the foreign-affairs trump'? ${ }^{12}$

This paper examines how two federal-type polities, Canada and the European Union, have taken up Thomas Franck's challenge as it pertains to the constitutional principle of federalism. How have Canadian and European constitutionalism responded to the tension between the domestic constitutional principle of federalism, on the one hand, and international law, on the other?

This paper argues that in both polities, the domestic constitutional value of federalism is still, to a large extent, put 'on hold' in the area of foreign affairs. That is, in constitutional terms, the authority to act internationally is still to a significant extent held or controlled by the order of government recognised by the international community as a sovereign State. This is in spite of an increase in international activities by Canadian provinces since the 1960s, and the emergence of the European Union as a foreign policy actor of significance-however slow

9 On this functional justification, see generally Peter Spiro, 'Foreign Relations Federalism' (1999) 70 U Colorado L Rev 1223, 1227-59; See also Ganesh Sitamaran and Ingrid Wuerth, 'The Normalization of Foreign Relations Law' (2015) 128 Harv L Rev 1897, 1906-18.

10 Sovereignty, in this sense, is based on an analogy with the individual in liberal thought. See, eg, Martti Koskenniemi, 'The Future of Statehood' (1991) 32 Harv Intern'l LJ 397, 404.

11 See Wolfgang Friedmann, The Changing Structure of International Law (Columbia UP 1964).

12 Thomas Franck, Political Questions/Judicial Answers: Does the Rule of Law Apply to Foreign Affairs? (Princeton UP 1992) 5; See also Spiro (n 9). 
and hesitant this emergence may be. ${ }^{13}$ In contrast to Canada, however, where the dualist wall continues to stand strong, the dominance of the sovereign State in the area of EU foreign affairs is liable to spill over into the EU's domestic legal order. This observation calls for a recalibration of the federal balance in Europe's foreign affairs constitution. Such a recalibration, it is suggested, should start by critically reappraising the use of the technique of mixity. ${ }^{14}$

The paper is structured as follows. An introductory section shows that both Canada and the European Union are federal in nature. The second and third sections examine the structure of the foreign affairs constitution of both federaltype polities. In a fourth section, a brief comparison will be made between both polities. The paper ends with an assessment of both federal-type polities' foreign affairs constitution in light of the federalism principle.

\section{Federalism as equal autonomy in Canada and the European Union}

Constitutionalism, both in Canada and the European Union, adheres to an understanding of federalism as equal autonomy. Kenneth Wheare defined federalism as the method of dividing government power so that the general and regional governments are each, within a sphere, co-ordinate and independent. ${ }^{15}$ Relying directly on Wheare, the Canadian Supreme Court stated in its 1998 Quebec Secession reference that:

In a federal system of government such as [Canada's], political power is shared by two orders of government: the federal government on the one hand, and the provinces on the other. Each is assigned respective spheres of jurisdiction by the Constitution Act, $1867 .^{16}$

13 For a critical appraisal, see Karen E Smith, European Union Foreign Policy in a Changing World (3rd edn, Polity Press 2014) 208-10.

14 On the technique of concluding mixed agreements (ie, agreements to which both the EU and the Member States are parties), see Christophe Hillion and Panos Koutrakos (eds), Mixed Agreements Revisited: The EU and its Member States in the World (Hart 2010).

15 Wheare (n 2) 10.

16 Reference re Secession of Quebec [1998] 2 SCR 217, (1998) 161 DLR $\left(4^{\text {th }}\right) 385$ [56]; On the central role of the Quebec Secession reference in Canadian federalism, see Robert S Schertzer, 'Judging the Nation: The Supreme Court of Canada, Federalism and Managing Diversity' (PhD thesis, London School of Economics and Political Science 2012) ch $4<$ http://ethos.bl.uk/ OrderDetails.do?uin=uk.bl.ethos.570991> accessed 4 January 2016. 
The Court continued: 'The principle of federalism recognizes the diversity of the component parts of Confederation, and the autonomy of provincial governments to develop their societies within their respective spheres of jurisdiction. ${ }^{17}$ More recently, the Supreme Court of Canada made similar statements in its Securities reference, where it held that:

It is a fundamental principle of federalism that both federal and provincial powers must be respected, and one power may not be used in a manner that effectively eviscerates another. Rather, federalism demands that a balance be struck, a balance that allows both the federal Parliament and the provincial legislatures to act effectively in their respective spheres. ${ }^{18}$

These statements point to a conception of the constitutional structure of Canada as consisting of two orders of government that stand in a relation of equal autonomy. This conception has a long standing in Canada. In the 1892 Maritime Bank case, Lord Watson, speaking on behalf of the Judicial Committee of the Privy Council (the Privy Council) held:

The object of the [Constitution Act 1867] was neither to weld the provinces into one, nor to subordinate provincial governments to central authority, but to create a federal government in which they should all be represented, entrusted with the exclusive administration of affairs in which they had a common interest, each province retaining its own independence and autonomy. ${ }^{19}$

Differences of opinion persist with regards to the origins and nature of the constitutional ties that bind the federal and provincial governments in Canada. ${ }^{20}$ Beyond contestation, however, is that any interpretation of Canada's constitution 
must take place within the confines of a normative theory in which provincial and federal governments stand in a relationship of equal autonomy.

Turning to Europe, in its seminal 1963 Van Gend \& Loos judgment, the Court of Justice of the European Union (CJEU) held that:

The [Union] constitutes a new legal order of international law for the benefit of which the states have limited their sovereign rights, albeit within limited fields, and the subjects of which comprise not only Member States but also their nationals. ${ }^{21}$

In Costa $v$ Enel, the Court dropped the reference to international law, referring to EU law instead as a 'body of law' and an 'independent source of law.' In subsequent decades, the Court of Justice continued on the path of what many have described as one of a 'constitutionalisation' of the EU legal order and institutional structure, allowing the late Eric Stein to characterise early 1980s European Economic Community law as 'a constitutional framework for a federaltype structure in Europe. ${ }^{, 23}$ At around the same time as the German Constitutional Court expressed its claim to ultimate authority in its 1992 Maastricht ruling, ${ }^{24}$ academic commentators undertook efforts to pass 'beyond the sovereign state' and develop a constitutional theory for the European Union in which the Union and Member State legal orders were conceived of as co-equal in character. ${ }^{25}$ Sir Neil MacCormick was arguably the first scholar of EU law to articulate this idea. In a 1993 article, he raised the following question:

Can we think of a world in which our normative existence and our practical life are anchored in, or related to, a variety of institutional systems, each of which has validity or operation in relation to some range of concerns, none of which is absolute over all the others, and all of which, for most purposes, can operate without serious mutual conflict in areas of overlap? ? $^{26}$

21 Case 26/62 Van Gend en Loos v Administratie der Belastingen [1963] ECR 1, para 12.

22 Case 6/64 Costa v ENEL [1964] ECR 585, 593-94.

23 Eric Stein, 'Lawyers, Judges, and the Making of a Transnational Constitution' (1981) 75 AJIL 1, 1; The Les Verts judgment plays an important symbolic role in this narrative, as it contains the first reference to the EU Treaties as a 'constitutional charter'. See Case 294/83 Parti écologiste 'Les Verts' $v$ European Parliament [1986] ECR 1339, para 23. BVerfGE 89, 155 (12 October 1993) 2 BvR 2134/92, 2159/92, para 165.

25 Neil MacCormick, 'Beyond the Sovereign State' (1993) 56 MLR 1.

26 ibid 17. 
Constitutional pluralism, as the theory became known, has become the dominant theory of European integration within EU legal circles, replacing the paradigm of classical constitutionalism described in the above. ${ }^{27} \mathrm{EU}$ constitutionalism gives expression to this theory of constitutional pluralism by combining the abovementioned claim to autonomy-the 'new legal order' claim-with a commitment towards protecting the national, including the constitutional, identity of the Member States. ${ }^{28}$

It is suggested that, despite differences in the conceptual structure of both compound polities, what unites both Canada and the European Union is an adherence to a constitutional principle of federalism understood as the pursuit of equal autonomy between both orders of government that together constitute a compound polity. ${ }^{29}$ In Canada, the federalism principle is expressed primarily at a hermeneutical level, ie, in the interpretation given to the division of legislative competences laid down in Canada's written constitution. In the EU, by contrast, it is expressed at a systemic level, ie, in the process of mutual accommodation between the EU and Member State legal orders. Regardless of these differences, in both polities, the best possible interpretation of the constitutional structure is one in which a respect for the equal autonomy of both levels of government plays a prominent role. In the remainder of this paper, this understanding of federalism as equal autonomy will act, to paraphrase Canada's Supreme Court, as the 'lodestar' by which the analysis of Canada and the EU's foreign affairs constitution will be guided. $^{30}$

For a recent discussion of the different strands in constitutional pluralist thought, see Jan Komárek and Matej Avbelj (eds), Constitutional Pluralism in the European Union and Beyond (Hart 2012); Classical constitutionalism refers to what Mattias Kumm referred to as the 'legalist monist' conception of the structure of the EU polity. See Mattias Kumm, 'Rethinking Constitutional Authority: On the Structure and Limits of Constitutional Pluralism' in Matej Avbelj and Jan Komárek (eds), Constitutional Pluralism in the European Union and Beyond (Hart 2012) 39-66, 43-47. Maastricht Treaty [1992] OJ C191/1 (TEU) art 4(2); On a role for this provision as a federalism safeguard in the EU, see François-Xavier Millet, 'National Constitutional Identity as a Safeguard of Federalism in Europe' (2012) EUI Working Paper 2012/06.

29 The similarities between the concept of federalism in the Anglo-American tradition and that of constitutional pluralism were noted in Robert Schütze, From Dual to Cooperative Federalism: The Changing Structure of European Law (OUP 2009) 13-74.

30 Reference re Secession of Quebec [1998] 2 SCR 217, (1998) 161 DLR (4 $\left.{ }^{\text {th }}\right) 385$ [56]: 'In interpreting our Constitution, the courts have always been concerned with the federalism principle, inherent in the structure of our constitutional arrangements, which has from the beginning been the lodestar by which the courts have been guided. 


\section{Federalism and foreign affairs in Canada}

How did Canadian constitutionalism address the challenge posed by the tension between the domestic principle of federalism and the international legal principle of sovereignty? As argued by a federal government lawyer:

The Constitution of Canada is a hybrid plant if ever there was one, deeply rooted in the soil of the British tradition of unwritten principles and conventions, but with most of its prominent offshoots-a written document, a federal provincial distribution of powers, an entrenched Charter, legal amending procedures, judicial review - grafted from the American genus and species. ${ }^{31}$

Absent any provisions on the subject of foreign affairs in Canada's written constitutional document-the Constitution Act 1867-it was the British constitutional tradition of unwritten principles and conventions that Canadian constitutionalism turned to in search of materials with which to craft a Canadian foreign affairs constitution. ${ }^{32}$

Looming large in British constitutional thought on the subject of foreign affairs were two notions: that of dualism and that of the royal prerogative. At a basic level, dualism means that the international and domestic legal orders are considered conceptually distinct. ${ }^{33}$ As a consequence of this separation, the validity of a domestic legal norm cannot be derived from an international legal norm. Validity within both legal orders must be derived from each legal order's rule of recognition. In practice, this means that for a treaty to have legal effect within domestic law, a form of normative action is required. In the United Kingdom, such action traditionally takes the form of a legislative act. Lord Atkin expressed this position well in the 1937 Labour Conventions case, where he held that 'within the British Empire there is a well-established rule that the making of a treaty is an executive act, while the performance of its obligations, if they entail alteration of

31 Warren J Newman, 'Of Castles and Living Trees: The Metaphorical and Structural Constitution' (Conference on Emerging Issues in Canadian Public Law, Ottawa, May 2015) 20-21.

32 See, however, s 132 of the Constitution Act 1867, empowering the federal Parliament to implement Imperial treaty obligations affecting Canada; The extension of the scope of this provision to include Canadian treaty obligations was rejected in the Labour Conventions case; See Attorney General of Canada v Attorney General of Ontario [1937] AC 326 (Labour Conventions).

33 In contrast to monism, according to which domestic and international law form a single legal order. See Hans Kelsen, Principles of International Law (The Lawbook Exchange 2003) 403-04. 
the existing domestic law, requires legislative action., ${ }^{34}$ The Labour Conventions case counts as a precedent both in the United Kingdom and in Canada. It confirmed the dualist orientation of Canada's foreign affairs constitution. As in the United Kingdom, a treaty cannot, in and by itself, be binding within Canadian law.

Next to dualism, the royal prerogative is the other central concept of the United Kingdom's foreign affairs constitution. In the United Kingdom, the concept operates as the constitutional foundation for the government's authority over foreign affairs. ${ }^{35}$ The concept has a long pedigree. ${ }^{36}$ Albert Venn Dicey defined the prerogative as the 'residue of discretionary or arbitrary authority, which at any given time is legally left in the hands of the Crown. ${ }^{37}$ Public authority over foreign affairs was generally understood as being part of the royal prerogative. ${ }^{38}$ The royal prerogative encompasses all actions traditionally understood as flowing from a polity's status as a sovereign State. This includes the power to make treaties (ius tractati) and the power to send and receive ambassadors and consuls abroad (ius legationis). ${ }^{39}$

The transplantation of concepts of British constitutionalism to Canadian soil raised questions regarding these concepts' compatibility with Canada's federal architecture. Two such questions are worth exploring: (i) Who was to be constitutionally empowered to exercise the foreign affairs prerogative: the federal Governor General (and thus in practice the federal government) and/or the

Labour Conventions [1937] AC 326, 347; For a more recent affirmation of this principle, see Baker $v$ Canada (Minister of Citizenship and Immigration) [1999] 2 SCR 817, (1999) 174 DLR $\left(4^{\text {th }}\right) 193$ [69], where Justice L'Heureux-Dubé held that '[i]nternational treaties and conventions are not part of Canadian law unless they have been implemented by statute.' See Ministry of Justice (UK), The Governance of Britain (Cm 7170, 2007) 16, describing the power to make treaties as a 'prerogative executive power'.

36 For an overview of the notion's historical origins and its historical role in the area of foreign affairs, see Campbell McLachlan, Foreign Relations Law (CUP 2014) 111-258. AV Dicey, Introduction to the Study of the Law of the Constitution (8th edn, Macmillan 1915) 424.

McLachlan (n 36) 117; For a confirmation of this position in the Canadian context, see Canada (Prime Minister) $v$ Khadr [2010] 1 SCR 44 [35]: 'The prerogative power over foreign affairs has not been displaced by s 10 of the Department of Foreign Affairs and International Trade Act (...) and continues to be exercised by the federal government. The Crown prerogative in foreign affairs includes the making of representations to a foreign government'.

Blackstone considered the following powers as falling within the scope of the foreign affairs prerogative: the power to appoint and to receive ambassadors, to make treaties with foreign states, to make war and peace, to exact reprisals for injury to his subjects by foreign states and to grant safe conduct for foreigners entering the nation. See McLachlan (n 36) 116, citing Bl Comm. 
provincial lieutenant governors (and thus in practice the provincial governments)? (ii) Which legislatures would be constitutionally empowered to implement treaties in Canadian law: the federal and/or the provincial legislatures?

\subsection{The prerogative and Canada's federal architecture}

As with other concepts and principles originally developed in a British context, questions were raised regarding the prerogative's relation to Canada's federal architecture. Canadian courts were presented with this challenge in the abovementioned Labour Conventions case. At issue was the constitutionality of federal legislation aimed at implementing a number of conventions adopted in the context of the International Labour Organization (ILO). The conventions addressed issues of labour law. As such, they touched on provincial legislative authority over property and civil rights in the province. ${ }^{40}$

The Ontario government launched a constitutional challenge against the federal implementing legislation. Before the Supreme Court of Canada and ultimately the London-based Privy Council, the Ontario government argued that it, too, possessed the constitutional authority to adopt the involved ILO conventions. ${ }^{41}$ At the Supreme Court of Canada, Chief Justice Duff rejected Ontario's plea on behalf of a 3-2 majority. He responded by stating that:

As a result of the constitutional development of the last thirty years (and more particularly of the last twenty years) Canada has acquired the status of an international unit, that is to say, she has been recognized by His Majesty the King, by the other nations of the British Commonwealth of Nations, and by the nations

40 Constitution Act 1867 s 92(13). The federal government accepted before the Privy Council that in a strictly domestic context, the federal Parliament would not have had the legislative competence to adopt the contested statutes.

41 The Ontario Government argued that ' $\mathrm{t}]$ here are no grounds whatever for saying that the parties to advise His Majesty in matters relating to the jurisdiction of the Provinces have in some way come to the Dominion Ministers. The Province has the right to advise the Crown in matters where its legislative powers apply. Ontario has the right to enter into an agreement with another part of the British Empire or with a foreign State.' Bernier (n 1) 52, citing Labour Conventions [1937] AC 326. 
of the world, as possessing a status enabling her to enter into, on her own behalf, international arrangements, and to incur obligations under such arrangements. ${ }^{42}$

Regarding the nature of that competence, Duff CJ begged the question: 'That this authority is exclusive would seem to follow inevitably from the circumstances that the Lieutenant-Governors of the provinces do not in any manner represent His Majesty in external affairs. ${ }^{43}$ The Privy Council did not consider it necessary to rule on the question of the impact of the federalism principle on the royal prerogative, although its ruling did appear to rely on the premise that only the federal government could exercise the royal prerogative to make treaties. ${ }^{44}$

The issue of the locus and possible division of the power over foreign affairs has been, and continues to be, a thorny one in Canada. It became a focal point for supporters of Quebec autonomy during that province's Quiet Revolution ${ }^{45}$ and up until today some commentators defend the position that the foreign affairs prerogative can be exercised also by the provincial lieutenant governors (and thus by the provincial governments). ${ }^{46}$ In addition, the government of Quebec itself continues to affirm, as former liberal premier Jean Charest held, that '[c]e qui est de compétence québécoise chez nous est de compétence québécoise partout!'-a proposition repeated by Quebec's current international relations minister as recently as the spring of $2015 .^{47}$ Despite these claims, Canadian courts nonetheless

Reference re legislative jurisdiction of Parliament of Canada to enact the Minimum Wages Act [1936] SCR 461, 462; (1936) 3 DLR 673; note that the Privy Council's Labour Conventions reference is the judgment in appeal against the Supreme Court of Canada's reference mentioned here.

43 ibid.

44 In this sense, see Stéphane Beaulac, 'The Myth of Jus Tractatus in La Belle Province: Quebec's Gerin-Lajoie Statement' (2012) 35 Dalhousie LJ 237, 250-52.

45 See, eg, the plea for a Quebec treaty-making power in JY Morin, 'La personnalité internationale du Québec' (1984) 1 Revue Québécoise de Droit International 163; See also the comparative analysis made nearly twenty years prior to this, before assuming a prominent role in the Quebec provincial government: JY Morin, 'La conclusion d'accords internationaux par les provinces canadiennes à la lumière du droit comparé' (1965) 3 Can YIL 127.

See generally Hugo Cyr, Canadian Federalism and Treaty Powers: Organic Constitutionalism at Work (Peter Lang 2009); Gibran van Ert, 'The Legal Character of Provincial Agreements with Foreign Governments' (2001) 42 Les Cahiers de Droit 1093.

47 Christian Dufour, 'La doctrine Gérin-Lajoie pour toujours' Journal de Montreal (Montreal, 29 March 2015) <http://service.vigile.quebec/La-doctrine-Gerin-Lajoie-pour> accessed 23 August 2015. 
continue to consider the foreign affairs prerogative a prerogative of the federal government only. ${ }^{48}$

\subsection{Treaty implementation and Canada's federal architecture}

Transplanting both dualism and the royal prerogative to Canadian soil raised yet another federalism question. Which Canadian legislature is constitutionally empowered to implement treaty obligations incurred by the federal government? In Australia, the Commonwealth Constitution explicitly allocates legislative competence over external affairs to the Commonwealth Parliament. ${ }^{49}$ As mentioned, in the United States, the Supreme Court held in Missouri v Holland that Congressional power to implement treaties is a necessary and proper means of effectuating a treaty. ${ }^{50}$ In Canada, by contrast, a similar general treaty-implementing power was rejected. In the same Labour Conventions case, Lord Atkin ruled that:

For the purposes of $(\ldots)$ the distribution of legislative powers between the Dominion and the Provinces, there is no such thing as treaty legislation as such. The distribution is based on classes of subjects: and as a treaty deals with a particular class of subjects so will the legislative power of performing it be ascertained. ${ }^{51}$

Put differently, the treaty origins of a statute do not affect the allocation of legislative competences in Canada; this allocation depends on substantive classes of subjects, not on the origins (domestic or international) or the type of instrument used. ${ }^{52}$ The

For a relatively recent confirmation of the position by the Quebec Court of Appeal, see $U L$ Canada Inc v Québec (A-G) (2003) 234 DLR ( $\left.4^{\text {th }}\right) 398$ [76] (Nuss JA): 'As a matter of International Law, a country is bound by a treaty from the moment it is ratified. In Canada, the Governor General has the Constitutional authority to ratify treaties'; Note that the Supreme Court of Canada itself has not revisited the issue since the remarks by Chief Justice Duff uttered in 1936. It did, however, on several occasions raise the possibility of overturning the Labour Conventions judgment. See, eg, MacDonald v Vapor Canada Ltd [1977] 2 SCR 134 [168ff] (Laskin CJ). Chief Justice Bora Laskin's opposition to Labour Conventions was well-known; See Bora Laskin, 'Some International Legal Aspects of Federalism: The Experience of Canada' in David Currie (ed), Federalism and the New Nations of Africa (Chicago UP 1964) 396.

49 Australian Constitution s 51 (xxix).

50 Missouri v Holland ( $\mathrm{n} 6$ ).

51 Labour Conventions [1937] AC 326, 351.

52 Note that the division of executive powers follows that of legislative powers in Canada. See The Bonanza Creek Gold Mining Company Limited v The King (1916) 1 AC 566, 579: 'The [Constitution Act 1867] has made a distribution between the Dominion and the provinces 
refusal to make dependent the scope of the federal Parliament's legislative authority on the exercise of the federal government's treaty-making power sits well with the dualist philosophy underpinning Canada's foreign affairs constitution. The power to make international legal commitments remains separate from the power to change Canadian law. The dualist wall remains impermeable.

The refusal to extend the federal Parliament's legislative powers to keep pace with the federal government's extended executive powers in the area of foreign affairs is an important feature of Canada's foreign affairs constitution, setting Canada apart from federations such as Australia and the United States. This refusal has certain federalism repercussions. If it is beyond doubt that a federally concluded treaty will require provincial legislative implementation, then the federal government is well advised to ensure provincial 'buy in' at the level of the negotiation of that treaty. Such is the case, for instance, with the CanadaEuropean Union trade agreement. Pressured in this direction by the European Union, Canadian provinces will implement the provisions of the treaty that touch on provincial heads of competence into domestic Canadian law. As a consequence, the federal government accepted a provincial role in the treaty negotiations. ${ }^{53}$

However, the impact of the Labour Conventions principle on the overall federal balance in Canada should not be overstated. The principle does not constitutionally entrench a role for the provincial governments in the federal treaty-making process. ${ }^{54}$ On many occasions, the federal Parliament will implement treaties, even if some provisions could be understood as touching on provincial

which extends not only to legislative but to executive authority (...) the distribution under the new grant of executive authority in substance follows the distribution under the new grant of legislative powers'.

Provinces have been making active use of the political leverage that they have been offered. In early 2015, the province of Newfoundland and Labrador threatened not to implement the EUCanada trade deal if it did not obtain federal funds in compensation for the potential job losses in the fisheries sector. See 'CETA Negotiations with Ottawa Suspended over Fisheries Fund, NL Says' CBC News (19 January 2015) <http://www.cbc.ca/news/canada/newfoundlandlabrador/ceta-negotiations-with-ottawa-suspended-over-fisheries-fund-n-l-says-1.2917699> accessed 14 August 2015.

The provincial premiers have requested a formalisation of a provincial role in federal treaty negotiations. To our knowledge, the federal government has not responded to this request. See Government of New Brunswick, 'Premiers Strengthen Trade' Communications New Brunswick (10 August 2007) <http://www.gnb.ca/cnb/news/iga/2007e1017ig.htm> accessed 14 August 2015. 
heads of competence. ${ }^{55}$ This observation does not come as a surprise considering the structure of domestic federalism in Canada. The recognition of jurisdictional overlap is coupled with a tolerance of Canadian courts towards the operability of legislation-federal or provincial-that touches on heads of power allocated to the other level of government. ${ }^{56}$ Such tolerance also exists in the context of foreign affairs, where one can expect federal implementing legislation in pith and substance in relation to a matter falling within a federal class of subjects to be considered intra vires the federal Parliament.

In summary, as holds true for Canada's domestic constitution, Canada's foreign affairs constitution can be understood as being 'similar in principle to that of the United Kingdom' albeit adapted to Canada's federal architecture. On the one hand, as in the United Kingdom, external sovereignty in Canada remains indivisible. Canada thus assimilates itself to the ideal-type of a unitary, sovereign State. On the other hand, the abovementioned dualist wall protects the legislative powers Canada's written constitution has allocated to the federal and provincial legislatures. This arrangement can be understood as a compromise between the need to ensure a smooth integration in the international legal order and the need to protect Canada's federal architecture.

55 It was uncertain, for instance, whether the federal Parliament had the constitutional authority to implement the entire North American Free Trade Agreement. Provincial governments had threatened to launch a constitutional challenge against the federal implementing legislation, but in the end refrained from doing so. On this subject, see H Scott Fairley, 'Foreign Affairs and the Canadian Constitution' (Biennial Conference of the International Law Association, Toronto, June 2006) <http://www.ila2006.org/fairley.pdf> accessed 5 January 2016.

56 On the 'flexible' nature of Canadian federalism, see Ontario (A-G) $v$ OPSEU [1987] 2 SCR 2, 27; $41 \operatorname{DLR}\left(4^{\text {th }}\right) 1,11$ (Dickson CJ): 'The history of Canadian constitutional law has been to allow for a fair amount of interplay and indeed overlap between federal and provincial powers. It is true that doctrines like interjurisdictional and Crown immunity and concepts like "watertight compartments" qualify the extent of that interplay. But it must be recognized that these doctrines and concepts have not been the dominant tide of constitutional doctrines; rather they have been an undertow against the strong pull of pith and substance, the aspect doctrine and, in recent years, a very restrained approach to concurrency and paramountcy issues'; See also Bruce Ryder, 'The Demise and Rise of the Classical Paradigm in Canadian Federalism: Promoting Autonomy for the Provinces and the First Nations' (1991) 36 McGill LJ $308,324-26$. 


\subsection{Principle and pragmatism in Canadian foreign affairs federalism}

How to square, however, the picture of an impermeable dualist 'wall' between the internal and the external realms with the empirical observation that Canadian provinces do develop certain forms of international action-actions which include at least in one province the conclusion of agreements with third country governments that this province considers to be legally binding? ? $^{57}$

It is suggested that a strict reading of the scope of the foreign affairs prerogative precludes Canadian provinces from making agreements that can be considered treaties within the meaning of the Vienna Convention on the Law of Treaties-treaty-making, it was mentioned above, being a central component of the foreign affairs prerogative. However, Canadian constitutionalism has opted for a pragmatic reading of the scope of the foreign affairs power that accommodates, if only partially, provincial claims to hold an independent treaty-making power. This pragmatic interpretation of the prerogative was suggested by Eward McWhinney in a 1969 contribution. This was shortly after the showdown between the federal and Quebec governments over the conclusion of an agreement between France and Quebec of which both parties considered to constitute a treaty under international law. McWhinney pleaded for:

enlisting the virtues of constitutional self-restraint and moderation and of not escalating into a federal-provincial constitutional crisis over foreign affairs and the treaty power, before one is sure that, in substance, it really is 'foreign affairs' or even 'treaties' that are involved [and not] simply a normal question of provincial legislative competence involving, at the same time, some trans-national aspects. ${ }^{58}$

The government of Quebec regularly concludes agreements with third countries on subjects covering the entire scope of its domestic competences. For an overview, see the database on the website of the Quebec International Relations ministry at <http://www.mrif.gouv.qc.ca/ en/Ententes-et-Engagements/Ententes-internationales $>$ accessed 29 August 2015; It should be noted that Quebec is not alone in undertaking international activities. For an early analysis, see Ronald G Atkey, 'The Role of the Provinces in International Affairs' (1970) 26 Intern'l J 249, 261; For a more recent contribution focussing on the area of international trade, see Christopher Kukucha, The Provinces and Canadian Foreign Trade Policy (UBC Press 2008). Impact of Quebec's “Quiet Revolution”' [1969] Can YB Int'l L 3, 10. 
It would appear that the federal government has taken up McWhinney's advice and embraced a pragmatic conception of the scope of the foreign affairs prerogative that leaves room for provincial international action without international legal consequences. While maintaining an uncompromising position at the level of principle, ${ }^{59}$ the federal government, to our knowledge, has not undertaken any legal challenges against provincial practices of making agreements with third country governments.

This arrangement can perhaps best be understood as an example of a constitutional abeyance. A constitutional abeyance, Michael Foley explains, is 'a form of tacit and instinctive agreement to condone, and even cultivate, constitutional ambiguity as an acceptable strategy for resolving conflict. ${ }^{60}$ Constitutional abeyances are only effective, however, in so far as disagreements over substance remain within certain limits. If and when genuine disagreement arises, constitutional questions left unanswered will most likely re-emerge. This would appear to be the case in Canada as well. ${ }^{61}$ If a Canadian province would desire to make an agreement with a third country government that would run counter to federal law or policy, it is to be expected that the federal government of Canada will attempt to prevent that province from doing so. The constitutional argument that foreign affairs remain federal affairs could, in such a situation, be used as another means of exercising leverage.

In summary, it is suggested that Canadian constitutionalism couples principle with pragmatism. The federal government holds an exclusive power to bind Canada under international law. It applies this power pragmatically, which allows provincial governments to make certain agreements with third countries. In case of disagreement between the federal and provincial governments, however, the federal government will be able to revert back to a more principled position,

59 The position of the federal government in this debate has been articulated in Paul Martin, Federalism and International Relations (The Queen's Printer 1968) 15-16, arguing that the treaty-making power is part of the federal royal prerogative, and that the power to exercise the prerogative has never been delegated to the provincial lieutenant-governors. As confirmed to the author in an interview, this white paper remains government policy today.

60 Michael Foley, The Silence of Constitutions: Gaps, 'Abeyances' and Political Temperament in the Maintenance of Government (Routledge 2011) xi.

61 See Can Erk and Alain-G Gagnon, 'Constitutional Ambiguity and Federal Trust: Codification of Federalism in Canada, Spain and Belgium' (2000) 10 Regional \& Federal Studies 92, suggesting that ambiguity only works as a strategy of pacification if sufficient trust exists between orders of government. 
precluding the provincial government from making the contested agreement. In the final analysis, therefore, it is argued that Canada's dualist wall stands strong. As far as the power to make commitments under international law is concerned, Canada presents itself to the outside world as a unitary, sovereign State. Constitutional restrictions on the exercise of the federal foreign affairs prerogative exist, ${ }^{62}$ but these do not include restrictions related to Canada's federal architecture.

\section{Federalism and foreign affairs in the European Union}

How did European constitutionalism address the challenge posed by the tension between the domestic principle of federalism and the international legal principle of sovereignty? As was the case with Canada's written constitution, the Treaty of Rome had little to say on the subject of foreign affairs. Only two treaty provisions empowered the then European Economic Communities to make treaties with third countries: the provision on the common commercial policy and that on the conclusion of association agreements. ${ }^{63}$ In the absence of a more elaborate written constitutional framework, the EU's foreign affairs constitution was shrouded in mystery. ${ }^{64}$ How, then, did European constitutionalism address the tension between the domestic constitutional value of federalism-as expressed in the EU's constitutional theory of constitutional pluralism-and international law's fundamental value of State sovereignty?

European constitutionalism addressed this challenge in two phases. In a first phase, the 'conceptual-federalist phase, ${ }^{65}$ federalism conflicts were avoided

63 Treaty Establishing the European Economic Community [1957] Not published [the EEC Treaty or Treaty of Rome], respectively, arts 113, 131.

64 Different schools had different views on the nature of the EU foreign affairs constitution. For a comparison, see the report of the 1969 conference held at the University of Liège, where Pierre Pescatore and Rolando Quadri defended opposing theories on the international legal personality of the Union. See Michel Melchior (ed), Les Relations Extérieures de La Communauté Européenne Unifiée. Actes Du Troisième Colloque Sur La Fusion Des Communautés Européennes Organisé à Liège Les 25, 26 et 27 Octobre 1967 (Institut d'études juridiques européennes de la Faculté de droit de l'Université de Liège 1969) 41-75 and 77-117.

65 Michel Waelbroeck introduced the distinction between competing conceptions of the EU's early foreign affairs constitution as a distinction between a 'conceptual-federalist' and a 'pragmatic' approach in M Waelbroeck, 'The Emergent Doctrine of Community Pre-Emption- 
and a smooth integration in the international legal order was facilitated through a strategy of a progressive 'exclusivisation' of Union external competences. In this normative vision, external sovereignty over areas covered by the European integration process-in particular areas (to be) covered by the so-called 'common policies'-would gradually be 'transferred' to the Union level of government. ${ }^{66}$ At least within those areas affected by the integration process, the Union institutions would be the holders of an external sovereignty not unlike that of the Union's treaty partners. Federalism was deemed protected sufficiently by the Member States' presence in the Council.

In a second phase, the 'pragmatic' phase, European constitutionalism abandoned this strategy of a progressive exclusivisation and instead pursued a strategy of a generalisation of shared competence in the foreign affairs area, coupled with a normative push towards joint action by the Union and the Member States. Member States and the Union institutions are invited to act collectively without the division of competences between both levels of government being clearly defined. In doing so, the Member States and the Union merge their external sovereignties so as to match the external sovereignty of their treaty partners. Unclear, however, is how the federalism principle is to fit into this arrangement. The Court of Justice appears willing to carve out a space in which federalism can be expressed at the level of the decision-making processes. As will be discussed, however, these efforts will remain unsatisfactory as long as it remains possible for Member States to become a party to an international agreement the EU could arguably conclude independently, thereby turning a proposed EU-only agreement into a mixed agreement.

Consent and Re-Delegation' in Terrance Sandalow and Eric Stein (eds), Courts and Free Markets: Perspectives from the United States and Europe (OUP 1982) 551-52. Waelbroeck was right in suggesting that both conceptions operated at the same time. It is suggested, however, that the history of the EU's foreign affairs constitution can be read as one of a gradual move from one conception to the other, whereby the 'pragmatic' conception gradually overtook the 'conceptual-federalist' reading as the dominant understanding of the structure of the EU's foreign affairs constitution.

66 It should be recalled from the outset that even in this ambitious understanding of the scope of the Union's external competences, it was not envisaged that the Union would replace the Member States entirely at the international level. As the Court of Justice already held in Case 26/62 Van Gend en Loos [1963] ECR 1, sovereignty was only transferred 'within limited fields'. 
4.1 The conceptual-federalist phase: transferring external sovereignty to the Union

The Court of Justice first pronounced itself on the subject of foreign affairs in the 1971 ERTA judgment. ${ }^{67}$ In what was incidentally the first inter-institutional dispute brought before the Court of Justice, ${ }^{68}$ the Commission requested that the Court annul Council proceedings regarding the negotiation and conclusion by the Member States of an international agreement on road transport. In the Commission's view, if adopted, the international agreement would come into conflict with an existing Union regulation. ${ }^{69}$ The Commission requested that the Court rule that 'where and to the extent to which the [Union] actually laid down such regulations, Member States lose their authority to legislate at the same level, and can only be called upon to take such measures as may be necessary to implement the [Union] provisions. ${ }^{70}$ The Council, followed by Advocate General Dutheillet de Lamothe, contested the Commission's argument. The Council argued instead that, absent an express attribution of powers to the Union, the Union did not hold any form of external competence, let alone an exclusive one. In its judgment of 31 March 1971, the Court followed the Commission as far as the question of principle was concerned. In particular, it ruled that:

Each time the [Union], with a view to implementing a common policy envisaged by the Treaty, adopts provisions laying down common rules, whatever form these may take, the Member States no longer have the right, acting individually or even collectively, to undertake obligations with third countries which affect those rules. ${ }^{71}$

The ERTA judgment pursued a double objective. On the one hand, from a foreign affairs perspective, the ERTA or 'pre-emption' doctrine can be understood as an

68 ibid para 284, Opinion of AG de Lamothe.

69 ibid para 270.

70 ibid.

71 ERTA [1971] ECR 263, 274, para 17. As far-reaching as the Court's argument appears to be, it did not benefit the Commission in that particular case. As the origins and a considerable amount of the work had been carried out before powers over transport had been transferred to the Union, the Court did allow the Member States to become Party to the road transport agreement, provided they acted throughout the treaty-making procedure in the interest of the Union: paras 84-90. 
expression of a normative vision of a gradual eclipsing of the Member States from the international arena through the adoption of internal Union legislation. ${ }^{72}$ The Court perhaps, and the Commission quite certainly, ${ }^{73}$ understood the establishment and gradual expansion of exclusive Union competence as the preferred constitutional answer to the challenge of 'fitting' into an international legal order made by and for sovereign States. By replacing the Member States at the international level in the areas concerned by the integration process, the Union would hold the attributes of external sovereignty. Federalism questions would not affect the Union's ability to 'speak with one voice' internationally. The Union would be on an equal footing with its treaty partners.

On the other hand, from a domestic federalism perspective, the ERTA judgment aimed to ensure that the Member States would not be able to undo by external means that which they had agreed to internally. As the Court held:

These [external Union] powers exclude the possibility of concurrent powers on the part of Member States, since any steps taken outside the framework of the [Union] institutions would be incompatible with the unity of the Common Market and the uniform application of [Union] law. ${ }^{74}$

In other words, by rendering exclusive external competence over areas within which domestic common rules had already been adopted, the Member States would not be in a position to affect, let alone undo, domestic EU norms by concluding international agreements with third countries. ${ }^{75}$ In this sense, the Court of Justice aimed to tackle a problem that mirrors the one presented to the Privy Council in Labour Conventions: in both cases, one level of government aimed to encroach on the competences of the other level of government through the exercise of the

72 Pierre Pescatore, Le droit de l'intégration: émergence d'un phénomène nouveau dans les relations internationales selon lexpérience des Communautés Européennes (Bruylant 2005) 44, arguing that in ERTA the Court of Justice confirmed a necessary link between the internal process of unification and the right to represent the Community on the international stage.

73 On the role of the European Commission's legal service in the development of an autonomous legal order more generally, see generally Julie Bailleux, 'Michel Gaudet, a Law Entrepreneur: The Role of the Legal Service of the European Executives in the Invention of EC Law and the Birth of the Common Market Law Review' (2013) CML Rev 359.

74 ERTA [1971] ECR 263, para 32.

75 Note that in 1971 it was not at all clear whether the primacy principle could apply to international action undertaken by the Member States. See Marise Cremona, 'The Doctrine of Exclusivity and the Position of Mixed Agreements in the External Relations of the European Community' (1982) 2 OJLS 393, 397-98. 
treaty-making power. ${ }^{76}$ The fundamental difference between the two cases was that the federalism question in Canada arose at the level of the implementation of treaties, while in the EU it arose at the level of their conclusion. ${ }^{77}$

Similar observations can be made in relation to those areas now considered as falling within the scope of the Union's so-called a priori exclusive competence. ${ }^{78}$ In the Treaty of Rome, the nature of the common commercial policy-to take the best-known example of this type of competence-was left undefined. ${ }^{79}$ The Court of Justice derived the exclusive character of the common commercial policy competence from what it considered its very nature or 'essence' as a policy that did not allow for concurrent Member State action. In Opinion 1/75, in particular, the Court of Justice held that the common commercial policy:

is conceived (...) in the context of the operation of the Common Market, for the defence of the common interests of the [Union], within which the particular interests of the Member States must endeavour to adapt to each other (...) Quite clearly, however, this conception is incompatible with the freedom to which the Member States could lay claim by invoking a concurrent power, so as to ensure that their own

For a similar observation in the EU-US context, see Eric Stein and Louis Henkin, 'Towards a European Polity? The European Foreign Affairs System from the Perspective of the United States Constitution' in M Cappelletti, M Seccombe and J Weiler (eds), Integration Through Law. Book 3: Forces and Potential for a European Identity (de Gruyter 1986) 43, pointing out that the ruling in ERTA could be seen as the 'exact reverse' of that in Missouri v Holland, 252 US 416 (1920).

In contrast to Canadian constitutionalism, which, as described, adheres to the philosophy of dualism, European constitutionalism from an early stage adhered to a philosophy of (qualified) monism. See already the judgment in Case 181/73 Haegeman v Belgium [1974] ECR 449, para 5: 'The provisions of the Agreement, from the coming into force thereof, form an integral part of [Union] law'; Monism is qualified in the European Union, however, since the Court of Justice acts as a 'gatekeeper' by subjecting the provisions of an international agreement to a direct effect test; For an example, see Case C-308/06 Intertanko [2008] ECR I-4057; On this subject, see Robert Schütze, Foreign Affairs and the EU Constitution: Selected Essays (CUP 2014) 50-54, comparing the direct effect test to the political question doctrine known in US constitutionalism.

78 Consolidated Version of the Treaty on the Functioning of the European Union [2012] OJ C326/47 (TFEU) art 3(1).

79 This led to some speculation as to the precise nature of the competence. See Ulrich Everling, 'Legal Problems of the Common Commercial Policy in the European Economic Community' (1967) 4 CML Rev 141, 150. 
interests were separately satisfied in external relations, at the risk of compromising the effective defence of the common interests of the [Union]. ${ }^{80}$

Here as well, the Court of Justice might have had in mind a desire to prevent federalism conflicts from occurring as well as a normative vision of a gradual replacement of the Member States by the Union institutions within the areas affected by the integration process. Through exclusivity, a smooth integration in the international legal order would be ensured; at the same time, federalism conflicts could be prevented.

However, this vision was difficult to accept for many Member States. Already in the ERTA case itself, the tension between the Court's expansive understanding of the scope of the Union's external competences had come into conflict with a Member State's insistence to remain visible at the international level. Thus in ERTA itself, the Court introduced the ERTA doctrine at the level of constitutional principle, but at the same time sought ways to justify that the Member States, rather than the Union, were to conclude the treaty involved. ${ }^{81}$

More far-reaching still, in Opinion 1/78, the Court of Justice felt compelled to accept a Council submission that the allocation of competence is affected by the fact that Member States would, to a significant extent, finance the operations of a proposed treaty regime. After confirming its statement of principle in Opinion $1 / 75$ regarding the nature of the common commercial policy-quoted in the above-the Court ruled that if:

the financing is to be by the Member States that will imply the participation of those States in the decision-making machinery or, at least, their agreement with regard to the arrangements for financing envisaged and consequently their participation in the agreement together with the Community. The exclusive competence of the Community could not be envisaged in such a case. ${ }^{82}$ Case 41/76 Suzanne Criel, née Donckerwolcke v Procureur de la République [1976] ECR 1921, paras 24-26.

81 The ERTA case laid the foundation for what is known today as the trustee doctrine. On this doctrine, see generally Marise Cremona, 'Member States as Trustees of the Union Interest: Participating in International Agreements on Behalf of the European Union' in Anthony Arnull and others (eds), A Constitutional Order of States? Essays in EU Law in Honour of Alan Dashwood (Hart 2011). Opinion 1/78 (International Agreement on Natural Rubber) [1979] ECR 2871, para 60. 
In other words, while maintaining its position of principle with regards to the nature of the common commercial policy, the Court from early on showed itself to be pragmatic in defining its scope.

\subsection{The pragmatic phase: merging external sovereignties}

In the early 1990s, it had become sufficiently clear that a gradual replacement of the Member States by the Union institutions would not occur in the near future. Member States were adamant to remain visible at the international stage. Presumably at least partially in response to this observation, ${ }^{83}$ in a number of Opinions, the structure of foreign affairs federalism in the European Union went through a process of transformation. Prior to that period, EU external action was undertaken within a normative framework which aimed to progressively endow the European Union with the attributes of external sovereignty, and in which the federal relationship between the Union and the Member States would be hidden behind a dualist wall. ${ }^{84}$ In the early 1990s, European constitutionalism moved to a normative framework in which the Union and the Member States would merge their external sovereignties to form what Robert Schütze has referred to as a 'plenipotentiary' whole.

This development had two aspects: first, it entailed a move away from a paradigm of exclusive external competences and an acceptance of the shared nature of both Union and Member State external competences; second, it implied an embrace of the technique of concluding mixed agreements.

83 Other factors being the experience of the genesis of the Maastricht Treaty, in which cracks in the permissive consensus around the European integration process were revealed, as well as the German Constitutional Court's Maastricht ruling, in which similar concerns were given judicial expression.

84 See in that regard Ruling 1/78 (IAEA Convention) [1978] ECR 2871, in particular para 35, where the Court considered the federal relationship to be a strictly domestic question of no interest to the Union's treaty partners.

Schütze (n 77) 202-03; Loïc Azoulai referred to this shift as one from a classical institutionalism, focussed on protecting the autonomy of the EU institutional framework towards a form of associative institutionalism; See Loïc Azoulai, 'The Many Visions of Europe: Insights from the Reasoning of the European Court of Justice in External Relations Law' in Marise Cremona and Anne Thies (eds), The European Court of Justice and External Relations Law: Constitutional Challenges (Hart 2014) 176-80. 
The generalisation of shared external competences was brought about primarily by means of a narrowing down of the ERTA doctrine. ${ }^{86}$ In Opinion $2 / 91$, the Court of Justice made a first step in this direction by recognising an ERTA-type exclusive Union competence only in relation to parts of a proposed international agreement. ${ }^{87}$ Other parts would fall under shared Union-Member State competence. A similar conclusion was reached in Opinion 1/94, where the Court required an area to have been harmonised completely before an ERTA-type exclusive Union competence could be recognised. ${ }^{88}$ In more recent case law, the Court took what Advocate General Bot referred to as a flexible approach. ${ }^{89}$ The application of the ERTA principle now depends on a 'comprehensive and detailed' analysis of the relationship between a proposed international agreement and common EU rules, in order to assess whether the agreement 'may affect common rules', as required by Article 3(2) TFEU. ${ }^{90}$ Putting aside the intricacies of the ERTA doctrine as interpreted by the Court in recent case law, it is clear that the era of an expansive reading of the ERTA doctrine has passed. ${ }^{91}$

This narrowing of the ERTA doctrine coincided with an embrace of the technique of mixity. In Opinion 2/91, the Court held that in cases in which a treaty cannot be brought entirely within exclusive Union competence, 'negotiation and implementation of the agreement require joint action by the [Union] and the Member States. ${ }^{92}$ In Opinion 1/94, the Court ambiguously concluded that the Member States and the Union were 'jointly' competent to conclude the General Agreement on Trade in Services and Agreement on Trade-Related Aspects of

86 In addition, it could be argued that the refusal to apply the so-called Opinion 1/76 or complementarity doctrine in any case after Opinion 1/76 also forms part of the Court's move towards the pragmatic paradigm; On the complementarity principle or doctrine, see Geert De Baere, Constitutional Principles of EU External Relations (OUP 2008) 52-58.

87 Opinion 2/91 (ILO) [1993] ECR I-1061.

88 Opinion 1/94 (WTO) [1994] ECR I-5267, para 96; On the implications of Opinion 1/94 on the structure of foreign affairs federalism in the EU, see generally N Emiliou, 'The Death of Exclusive Competence?' (1996) 21 EL Rev 294.

89 See Case C-66/13 Green Network SpA v Autorità per l'energia elettrica e il gas [2014] ECR I-3377, Opinion of AG Bot, paras 43-48, where he identified three phases in the Court's interpretation of the ERTA principle: an initial broad interpretation, a later stricter interpretation, and finally a more flexible interpretation.

90 See Opinion 1/13 (Convention on the Civil Aspects of Child Abduction) [2014] ECR I-2303, paras 70,74 .

91 For an analysis of the post-Lisbon ERTA case law, see Thomas Verellen, 'The ERTA Doctrine in the Post-Lisbon Era' (2015) 21 CJEL 383-410. 
Intellectual Property Rights - a conclusion that perhaps revealed the degree to which 'shared' competence was conflated with the technique of concluding mixed agreements. ${ }^{93}$ To our knowledge, in subsequent case law, in the area of foreign affairs, the choice for mixity has itself never been contested.

By embracing mixity, the Court of Justice accepted that the division of competences in the external context be left in abeyance. As was arguably the case with the scope of the foreign affairs prerogative in Canada, the practice of mixed agreements is another example of what Michael Foley referred to as 'a constitutional abeyance'. As Geert De Baere argued:

Their lack of clarity as to the precise vertical division of competences makes mixed agreements suitable for enabling the Union to act internationally while keeping the competence situation sufficiently vague so as not to affect openly the Member States' external competences. ${ }^{94}$

As 'mixity' prevents the federal relationship in the EU from being settled at the level of the division of competences, federalism questions have started to appear at the level of the Union institutional structure itself. In particular, in three recent interinstitutional cases, the Court was asked to clarify the terms of the decision-making procedures on the basis of which EU external action is to be undertaken. ${ }^{95}$ In the two cases in which the Grand Chamber of the Court has rendered judgment at the time of writing, as well as in Advocate General Sharpston's Opinion in a third case, the autonomy of the Union's legal and institutional order was given priority over that of the Member States. The full effectiveness of the text of the Treaties was given priority over arguments derived from the principle of sincere cooperation

94 Geert De Baere, 'EU External Action' in Catherine Barnard and Steve Peers (eds), European Union Law (OUP 2014) 738. decisions used during the treaty-making process-a practice which, in the Commission's view, undermined the autonomy of the Union institutional structure as it indirectly reintroduced decision-making by consensus and thus unanimity in the Council; In C-425/13 Commission $v$ Council [2015] ECLI:EU:C:2015:483, the Commission took aim at what it considered an unconstitutional infringement by the Council of its prerogative to represent the Union externally; Conversely, in C-73/14 Council v Commission [2015] ECLI:EU:C:2015:663 (ITLOS), the Council launched a constitutional challenge against what it considered an overly expansive reading of the same Commission prerogative to represent the Union externally. 
and the need to protect the 'unified international representation of the Union and the Member States. ${ }^{96}$

This shift of emphasis away from the need to work closely to ensure the unified international representation of the Union and towards a greater emphasis on the 'prerogatives' of the different Union institutions could pave the way for a recalibration of the federal balance in the EU's foreign affairs constitution. Rather than putting mixity itself into question, the Court appears to opt for an indirect strategy of strengthening the institutional position of the Union institutions within the mixed treaty-making procedure.

Yet, the recalibration put in motion in these cases has pitfalls, if only because it leaves untouched the conceptual structure within which the treaty-making process in all three cases takes place, ie that of a hybrid process characterised both by EU and international legal elements. ${ }^{97}$ By prioritising the former over the latter, the autonomy of the latter is undermined. More precisely, as the Court of Justice pushes towards greater autonomy for the Union institutions within a mixed framework, the tension between EU law (protecting the autonomy of the Union) and international law (protecting the autonomy of the Member States) will increase. That is, ensuring the full effectiveness of EU law within a hybrid EUinternational legal arrangement implies a violation of international law's central value of State sovereignty. Arguably, this approach is reminiscent more of a classical effet utile-focussed conception of EU constitutionalism than it is of a conception of the structure of the European integration project as one in which two orders of government stand in a relationship of equal autonomy.

\section{Comparing the European Union and Canada}

What differences and similarities exist in the ways European and Canadian constitutionalism have addressed Thomas Franck's challenge? How did European

96 In US Air Transport Agreement [2015] ECLI:EU:C:2015:282, para 55, the Court dispelled the Council's argument that the use of hybrid decisions should be seen as an expression of the duty of sincere cooperation and thus of the requirement of a unified international representation of the Union and the Member States with a brief yet telling swoop that '[the principle of sincere cooperation] cannot justify the Council setting itself free from compliance with the procedural rules and voting arrangements laid down in Article 218 TFEU'.

97 For a further elaboration of this argument, see Thomas Verellen, 'On Hybrid Decisions, Mixed Agreements and the Limits of the New Legal Order: Commission v Council ('US Air Transport Agreement')' (2016) 53(3) CML Rev 741. 
and Canadian constitutionalism address the tension between the domestic constitutional principle of federalism and international law's fundamental value of sovereignty? The comparison will take place in two steps. In a first step, the allocation of foreign affairs competences will be examined; in a second step, the exercise of these competences.

\subsection{The allocation of competences}

How have competences over foreign affairs been allocated in the European Union and Canada? At the level of competence allocation, in both federal-type polities, foreign affairs were initially considered federal affairs. In Canada, the power to bind oneself under international law was allocated exclusively to the federal government. In the European Union, the doctrines of pre-emption (ERTA) and $a$ priori exclusivity were designed to put into motion a gradual transfer of external sovereignty over areas covered by the European integration process to the Union order of government. As European integration progressed, the European Union would gradually replace the Member States within the international arena.

However, in both polities, this initial understanding of the division of competences came into conflict with the international ambitions of the other level of government-the Canadian provinces and the European Member States. This conflict led to a softening of the terms of the allocation of foreign affairs powers to the federal order of government. In both polities, opportunities arose for the member units of the federation to also undertake international activities. In Canada, this softening occurred at the level of the enforcement of existing principles, whereby the federal government refrained from enforcing its reading of the constitutional settlement before the courts-a strategy that allows the provincial governments some leeway to make agreements with third countries. In the European Union, this softening occurred at the level of the articulation of the abovementioned doctrines. As the ERTA doctrine was narrowed, and as the expansion of the scope of a priori competences was put to a halt, European constitutionalism moved to a structure of shared competences. Under this arrangement, both the Union and the Member States in principle hold vast, albeit shared, treaty-making competences.

In short, in both federal-type polities, constitutionalism allows for both orders of government to undertake international activities. Only in the European Union, however, is this ability incorporated in the articulation of the division of competences. 


\subsection{Exercise of competences}

Turning to the level of the exercise of competences, it is useful to make a distinction between direct and indirect restrictions on the exercise of foreign affairs competences. In Canada only indirect restrictions exist; in the EU, both direct and indirect restrictions exist.

Canada is typically considered a dualist federal system. ${ }^{98}$ This means that, once it is established that a matter falls within the jurisdiction of one order of government, that government can exercise its competence over the matter involved freely. In Canada, this feature flows from the fusion of federalism and parliamentary supremacy: while in Canada, an encompassing supremacy as the one held by the UK Parliament is not conceivable, each legislature is nonetheless considered to reign supreme within the sphere allocated to it by Canada's written constitution. ${ }^{99}$ However, the philosophy of dualism as expressed in the Labour Conventions case does potentially limit the federal government's freedom to exercise the federal foreign affairs prerogative. If it is established that a matter falls within a class of subjects allocated to the provincial legislatures, the federal government is well advised to ensure provincial 'buy in' at the level of the negotiation of treaties, for it will not be able to force the provincial legislatures to implement Canada's treaty obligations. Even though this indirect federalism safeguard lost some of its effectiveness in an era of flexible federalism in which competences de facto overlap significantly, it is suggested nonetheless that this feature of Canadian federalism does remain a factor to be taken into account by the federal government. ${ }^{100}$

In the European Union, restrictions on the exercise of competence are both direct and indirect. They are direct, as the duty of sincere cooperation restricts the Member States in their ability to exercise shared foreign affairs competences

98 See, eg, Joanne Poirier, 'Taking Aim at Cooperative Federalism: The Long-Gun Registry Decision by the Supreme Court of Canada' I-CONnect (15 April 2015) <http://www. iconnectblog.com/2015/04/taking-aim-at-cooperative-federalism-the-long-gun-registrydecision-by-the-supreme-court-of-canada/> accessed 26 August 2015.

99 See, most recently, Quebec (A-G) v Canada (A-G) [2015] 1 SCR 693, 383 DLR $\left(4^{\text {th }}\right) 614$ [20] (Cromwell and Karakatsanis JJ), holding that parliamentary sovereignty would be undermined if restrictions were put on the exercise of legislative competences in the name of a principle of 'cooperative federalism'.

100 In this sense, see, eg, Christopher J Kukucha, 'From Kyoto to the WTO: Evaluating the Constitutional Legitimacy of the Provinces in Canadian Foreign Trade and Environmental Policy' (2005) 38 Canadian J Pol Sci 129, 130-31, suggesting that enduring constitutional ambiguities creates motivation for federal-provincial cooperation. 
independently from the other Member States and from the Union institutions. ${ }^{101}$ Member States must consult with the Union institutions before undertaking foreign affairs action once some form of concerted Union strategy exists. On some occasions-without it being clear when exactly ${ }^{102}$-Member States are constitutionally required to refrain from acting all together. The result of the emergence of this duty of sincere cooperation, it is suggested, is that Member States are exposed to a significant normative pressure to act within a collective Union framework. To paraphrase Christopher Bickerton, to an important extent, European foreign affairs constitutionalism transformed Europe's nation-states into Member States. ${ }^{103}$

Restrictions are also indirect. The widespread availability of mixity, in effect, leaves the division of competences in abeyance. Absent clarity on the division of competences, the Union order of government is put in a disadvantageous position vis-à-vis the Member States. For the Union, absent a clear mandate given to it by the Treaties, cannot act internationally; the Member States, by contrast, each hold an original, as opposed to a functional, form of international legal personality and can thus act without prior authorisation by the Treaties. Shared competences combined with unlimited mixity prevent the Union from acting autonomously at the international level. As the late Pescatore wrote in a 1999 contribution: 'Mixity combined with a presumption for the competence of Member States is (...) a way of whittling down systematically the personality and capacity of the [Union] as a representative of the collective interest. ${ }^{104}$

In summary, Canadian constitutionalism restricts the ability of the federal government as the sole holder of foreign affairs powers in an indirect manner. European constitutionalism restricts the ability of both the Member States and the Union order of government to act independently at the international level. More

101 In this sense, see Case C-246/07 Commission v Sweden (PFOS) [2010] ECR I-3317, paras 7475.

102 A criticism expressed in Andres Delgado Casteleiro and Joris Larik, 'The Duty to Remain Silent: Limitless Loyalty in EU External Relations?' (2011) 36 EL Rev 524, 538-39.

103 See generally, Christopher J Bickerton, European Integration: From Nation-States to Member States (OUP 2012), arguing that national authority in EU Member States is exercised primarily through external-in particular EU-rules and norms; For a further development of this strand of thought, as well as a critical assessment, see Christopher J Bickerton, Dermot Hodson and Uwe Puetter, The New Intergovernmentalism: States and Supranational Actors in the Post-Maastricht Era (OUP 2015).

104 Pierre Pescatore, 'Opinion 1/94 on "Conclusion" of the WTO Agreement: Is There an Escape from a Programmed Disaster?’ (1999) 36 CML Rev 387, 388. 
precisely, in Canada, the federal government is the only order of government that can act internationally, but, in doing so, it must take into account provincial interests. In the European Union, all governments can act autonomously in theory, but in practice all governments must act collectively.

\section{Conclusion: equal autonomy, also in foreign affairs?}

In conclusion, it is argued that both in Canada and the European Union federalism is, to an important extent, put 'on hold' in the area of foreign affairs. The division of legislative competences does not affect the treaty-making power in Canada, making the federal government the only government actor empowered to make commitments under international law. In the European Union, the combination of loyalty with mixity moulds the Union and the Member State governments into a plenipotentiary whole-a strategy that might facilitate the integration of the Union into the international legal order, but only at the price of surrendering its ability to act independently from the Member States.

In the final analysis, however, European constitutionalism would appear to be less respectful of the federalism principle than is its Canadian counterpart. In Canada, the philosophy of dualism - the dualist 'wall' or 'veil'-protects Canada's domestic federal architecture. Despite its broad foreign affairs powers, the federal government cannot overturn the division of legislative powers laid down in Canada's written constitution. The power to legislate remains divided, and the federal government cannot change Canadian domestic law through its use of the prerogative power. ${ }^{105}$ In the European Union, by contrast, international agreements concluded by the EU are binding within the EU legal order, where they rank below primary law, but above secondary law. ${ }^{106}$ If the conditions for direct effect are met, provisions of an international agreement have primacy over Member State law as well as over domestic Union legislation. ${ }^{107}$

105 Baker v Canada (Minister of Citizenship and Immigration) [1999] 2 SCR 817, 174 DLR (4 $\left.{ }^{\text {th }}\right) 193$ [67] (McLachlin J).

106 TFEU (n 78) art 216(2); Intertanko [2008] ECR I-4057, para 42; Joined Cases C-402/05 P and C-415/05 P Yassin Abdullah Kadi and Al Barakaat International Foundation [2008] ECR I-6351, para 285.

107 On the conditions for provisions of international agreements to have direct effect in the EU legal order, see Case C-363/12 Z v A Government Department [2014] ECLI:EU:C:2014:159, para 85. 
The EU's federal architecture, therefore, would appear to be less protected against the joint exercise of foreign affairs powers by the EU and the Member States than Canada's architecture is against the federal government's use of the foreign affairs prerogative. When participating in the negotiation and conclusion of mixed agreements, the Member States' role in the decision-making process is more pronounced than it is in a domestic EU context. This feature, coupled with the potential direct effect of the resulting treaty, undermines the institutional position of the supranational institutions, in particular the Commission and the Parliament.

This observation only further highlights the pernicious effects of mixity on the overall federal balance in the European Union. If one is committed to the notion of a European Union that is more than the sum of its parts, this paper suggests that the first place to look for remedies for this imbalance is at the elephant in the room that prevents federalism as equal autonomy from being expressed in the EU's foreign affairs constitution: the possibility for the Member States to turn EU agreements into mixed agreements, without this possibility being subject to meaningful federalism safeguards. 